\title{
Gene Expression Patterns in Brachiopod Larvae Refute the "Brachiopod-Fold" Hypothesis
}

\author{
Andreas Altenburger ${ }^{1 *}$, Pedro Martinez ${ }^{2,3}$, Graham E. Budd ${ }^{4}$ and Lars E. Holmer ${ }^{4}$ \\ ${ }^{1}$ Section for Evolutionary Genomics, Natural History Museum of Denmark, University of Copenhagen, Copenhagen, \\ Denmark, ${ }^{2}$ Department of Genetics, University of Barcelona, Barcelona, Spain, ${ }^{3}$ Institut Català de Recerca $i$ \\ EstudisAvancats, Barcelona, Spain, ${ }^{4}$ Department of Earth Sciences, Palaeobiology, Uppsala University, Uppsala, Sweden
}

Keywords: Brachiopoda, body plan, evolution, brachiopod fold, gene expression, ontogeny

OPEN ACCESS

Edited by:

Nigel Hughes,

University of California, Riverside,

United States

Reviewed by:

Sandra Jean Carlson,

University of California, Davis,

United States

Scott Santagata,

LIU Post, United States

*Correspondence:

Andreas Altenburger aaltenburger@snm.ku.dk

Specialty section

This article was submitted to Evolutionary Developmental Biology,

a section of the journal

Frontiers in Cell and Developmental

Biology

Received: 23 May 2017 Accepted: 07 August 2017 Published: 22 August 2017

Citation:

Altenburger A, Martinez P, Budd GE and Holmer LE (2017) Gene

Expression Patterns in Brachiopod Larvae Refute the "Brachiopod-Fold" Hypothesis. Front. Cell Dev. Biol. 5:74. doi: 10.3389/fcell.2017.00074
Brachiopods represent an animal phylum of benthic marine organisms that originated in the Cambrian. About 400 recent species are known from today's oceans (Emig et al., 2013). Around 5,000 fossil genera have been described, as brachiopods were dominant in the benthic marine environment during the Palaeozoic (Logan, 2007). Brachiopods have a biphasic life cycle with a planktonic larvae and sessile adults (Figure 1A). The phylum is divided into three clades namely Rhynchonelliformea and Craniiformea, which have short-lived lecithotrophic larvae and Linguliformea, which have long lived planktotrophic larva (Williams et al., 1996; Carlson, 2016).

Although various candidate stem-group brachiopods are known (Holmer et al., 2002, 2008, 2011; Balthasar, 2004; Skovsted et al., 2009a,b), no single hypothesis of early brachiopod body plan evolution yet commands a consensus, despite the potential of the Cambrian fossil record for reconstructing early body plan evolution in this, or any other, animal phylum (Budd and Jensen, 2000; Budd and Jackson, 2016). Thus, the early evolution of brachiopods is still a matter of debate and has led to the proposal of various scenarios with varying degrees of support.

One such scenario is the hypothesis of a "brachiopod fold," which argues that brachiopods are transversely folded across the ontogenetic anterior-posterior axis (Figure 1B) (Cohen et al., 2003; Bitner and Cohen, 2013). According to this hypothesis, both valves are considered dorsal and in order to make useful comparisons with other animal phyla along the major body axis, brachiopods should be conceptually unfolded (Cohen et al., 2003). Since its original formulation, the brachiopod-fold hypothesis has gained support by some researchers in the brachiopod community with the suggestion that brachiopods arose by the folding of a Halkieria-like organism containing two protective shells at either end of the body (Benton and Harper, 2009). According to the brachiopod fold hypothesis, a folding process occurs during larval metamorphosis, as a rapid muscle mediated process that moves the posterior and anterior region of the larvae close together (Cohen et al., 2003). In this context, one hint about whether or not both valves can be considered dorsal would come from the analysis of gene expression patterns of developmental genes that are highly conserved among phyla. Such genes are ancient and can be traced to the last common ancestor of bilaterian animals (Schwaiger et al., 2014). If brachiopods evolved from a Halkieria-like organism by folding, one would expect the expression of genes that control the anterior and posterior domains in close proximity and opposed to each other.

Several studies have investigated the expression patterns of developmental genes in lecithotrophic brachiopod larvae (Altenburger et al., 2011; Santagata et al., 2012; Passamaneck et al., 2015; Martín-Durán et al., 2016; Vellutini and Hejnol, 2016). In these analyses it has been shown that during development the genes six3/6, NK2.1, gsc and otx are expressed in the anterior domain, which becomes the apical lobe in the rhynchonelliform Terebratalia transversa larva, and also in the anterior domain of the craniiform Novocrania anomala larva (Martín-Durán et al., 2016). Conversely, the genes $e v x$ and $c d x$ ("posterior genes") are expressed in the area that becomes the pedicle lobe and the posterior domain of the mantle lobe in T. transversa, and also in 
the posterior domain of the posterior lobe in N. anomala (Figure 1C) (Altenburger et al., 2011; Martín-Durán et al., 2016). Hox genes are not expressed collinearly in these brachiopod larvae (Schiemann et al., 2017). Analysis of the Hox cluster in T. transversa showed a split into three subclusters similar to that observed in other spiralians, such as in the annelid Capitella teleata and the limpet mollusc Lottia gigantea (Schiemann et al., 2017). Gene expression data for individuals during metamorphosis and for juveniles are still missing. Expression of Scr and Antp in the shell-forming epithelia of N. anomala and T. transversa larva suggests a role of these genes during juvenile shell formation (Schiemann et al., 2017).

The expression patterns of "anterior" and "posterior" genes in lecithotrophic brachiopod larvae are in an anterior-posterior sequence similar to the expression domains as detected in, for example, annelids and sea urchin embryos (Wei et al., 2012; Martín-Durán et al., 2016). As the morphogenetic events occurring during metamorphosis are known for T. transversa and N. anomala, it is possible to trace the body axes to the post-metamorphic body plan, and there are no signs of a folding event. Cohen et al. (2003) based the brachiopod fold hypothesis on observations during metamorphosis of N. anomala (Nielsen, 1991). However, a re-evaluation of metamorphosis in N. anomala showed that larva settle with the posterior-most tip of the posterior larval lobe and that vental and dorsal valves are not secreted from the same tissues (Altenburger et al., 2013).

Since there is no folding event during metamorphosis in craniiform or rhynchonelliform brachiopods (Altenburger and Wanninger, 2009; Altenburger et al., 2013), we can clearly state that there is no evidence in brachiopod ontogeny that supports the brachiopod fold hypothesis. Moreover, the only known exceptionally preserved lower Cambrian rhynchonelliform brachiopod Kutorgina chengjiangensis clearly has a straight gut (Zhang et al., 2007), indicating that the body axis orientation of brachiopods has been retained since the Cambrian.

\section{CONCLUSION}

Even though the data currently available do not allow for a conclusive hypothesis on the evolution of the brachiopod body plan, it is clear from the newly available gene expression data that the brachiopod fold hypothesis should be discarded and an alternative hypothesis for the evolution of brachiopod body plan is needed. One alternative scenario would involve a stemgroup brachiopod with a tubular sclerite arrangement (Skovsted et al., 2009c; Murdock et al., 2014). A major argument for the brachiopod fold hypothesis was the presence of a U-shaped gut in some brachiopods (Cohen et al., 2003). The main group of living brachiopods which have a U-shaped gut are the Linguliformea (Kaesler, 1997; see also Carlson, 2016 for an updated phylogenetic discussion). Unfortunately, the expression patterns of "anterior" and "posterior" genes are not known for this group. This lack of data constitutes a major obstacle in trying to understand the body plan evolution within the Brachiopoda and other lophophorates. However, a U-shaped gut is already clearly present in early

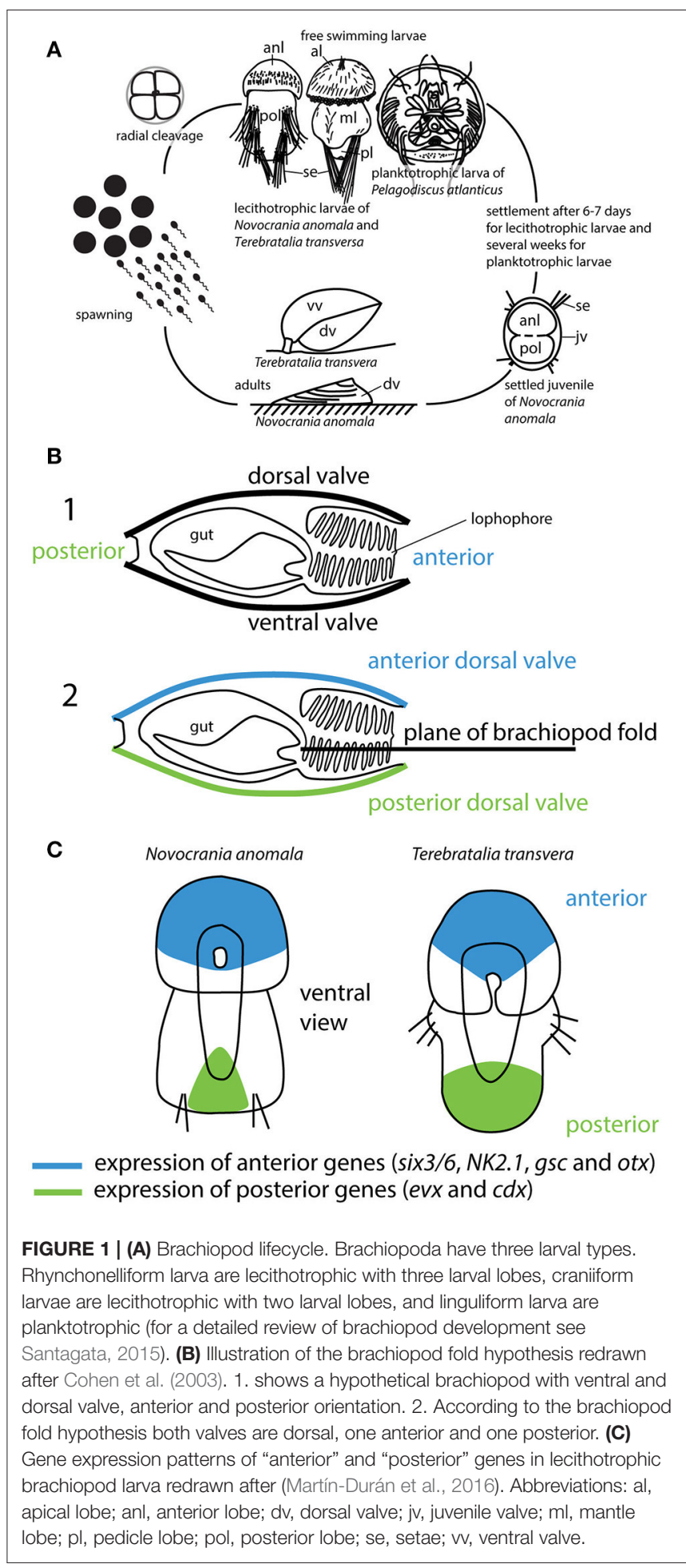

Cambrian stem lophophorates and brachiopods (Zhang et al., 2013, 2014), and even more recent findings (Moysiuk et al., 2017) have supported the suggestion that a tubular mode of life may be plesiomorphic within at least the lophotrochozoans (Budd and Jackson, 2016). 


\section{AUTHOR CONTRIBUTIONS}

AA designed the paper. AA, PM, GB, and $\mathrm{LH}$ wrote the paper.

\section{REFERENCES}

Altenburger, A., Martinez, P., and Wanninger, A. (2011). Homeobox gene expression in Brachiopoda: the role of Not and Cdx in bodyplan patterning, neurogenesis, and germ layer specification. Gene Exp. Patterns 11, 427-436. doi: 10.1016/j.gep.2011.07.001

Altenburger, A., and Wanninger, A. (2009). Comparative larval myogenesis and adult myoanatomy of the rhynchonelliform (articulate) brachiopods Argyrotheca cordata, A. cistellula, and Terebratalia transversa. Front. Zool. 6:3. doi: 10.1186/1742-9994-6-3

Altenburger, A., Wanninger, A., and Holmer, L. E. (2013). Metamorphosis in Craniiformea revisited: Novocrania anomala shows delayed development of the ventral valve. Zoomorphology 132, 379-387. doi: 10.1007/s00435-013-0194-3

Balthasar, U. (2004). Shell structure, ontogeny and affinities of the lower Cambrian bivalved problematic fossil Mickwitzia muralensis Walcott, 1913. Lethaia 37, 381-400. doi: 10.1080/00241160410002090

Benton, M.J., and Harper, D. A. T. (2009). Introduction to Paleobiology and the Fossil Record. Oxford: Wiley-Blackwell.

Bitner, M. A., and Cohen, B. L. (2013). "Brachiopoda," in eLS (Chichester: John Wiley \& Sons, Ltd), 1-8. doi: 10.1002/9780470015902.a0001614.pub3

Budd, G. E., and Jackson, I. S. C. (2016). Ecological innovations in the Cambrian and the origins of the crown group phyla. Philos. Trans. R. Soc. Lond. B Biol. Sci. 371:20150287. doi: 10.1098/rstb.2015.0287

Budd, G. E., and Jensen, S. (2000). A critical reappraisal of the fossil record of the bilaterian phyla. Biol. Rev. 75, 253-295. doi: 10.1111/j.1469-185X.1999.tb00046.x

Carlson, S. J. (2016). The evolution of Brachiopoda. Annu. Rev. Earth Planet. Sci. 44, 409-438. doi: 10.1146/annurev-earth-060115-012348

Cohen, B. L., Holmer, L. E., and Lüter, C. (2003). The brachiopod fold: a neglected body plan hypothesis. Palaeontology 46, 59-65. doi: 10.1111/1475-4983.00287

Emig, C. C., Bitner, M. A., and Álvarez, F. (2013). Phylum brachiopoda. Zootaxa 3703:75. doi: 10.11646/zootaxa.3703.1.15

Holmer, L. E., Skovsted, C. B., Brock, G. A., Valentine, J. L., and Paterson, J. R. (2008). The Early Cambrian tommotiid Micrina, a sessile bivalved stem group brachiopod. Biol. Lett. 4, 724-728. doi: 10.1098/rsbl.2008.0277

Holmer, L. E., Skovsted, C. B., Larsson, C., Brock, G. A., and Zhang, Z. (2011). First record of a bivalved larval shell in Early Cambrian tommotiids and its phylogenetic significance. Palaeontology 54, 235-239. doi: 10.1111/j.1475-4983.2010.01030.x

Holmer, L. E., Skovsted, C. B., and Williams, A. (2002). A stem group brachiopod from the lower Cambrian: support for a Micrina (halkieriid) ancestry. Palaeontology 45, 875-882. doi: 10.1111/1475-4983.00265

Kaesler, R. (1997). Treatise on Invertebrate Paleontology, Part H. Brachiopoda Revised 1. Boulder, CO; Lawrence, KS: Geological Society of America; University of Kansas Press.

Logan, A. (2007). "Geographic distribution of extant articulated brachiopods," in Treatise on Invertebrate Paleontology, Part H, Brachiopoda, ed P. A. Selden (Boulder, CO; Lawrence, KS: The Geological Society of America, Inc.; The University of Kansas), 3082-3115.

Martín-Durán, J. M., Passamaneck, Y. J., Martindale, M. Q., and Hejnol, A. (2016). The developmental basis for the recurrent evolution of deuterostomy and protostomy. Nat. Ecol. Evol. 1:0005. doi: 10.1038/s41559-016-0005

Moysiuk, J., Smith, M. R., and Caron, J.-B. (2017). Hyoliths are Palaeozoic lophophorates. Nature 541, 394-397. doi: 10.1038/nature20804

Murdock, D. J. E., Bengtson, S., Marone, F., Greenwood, J. M., and Donoghue, P. C. J. (2014). Evaluating scenarios for the evolutionary assembly of the brachiopod body plan. Evol. Dev. 16, 13-24. doi: 10.1111/ede.12059

Nielsen, C. (1991). The development of the brachiopod Crania (Neocrania) anomala (O. F. Müller) and its phylogenetic significance. Acta Zool. Stockh. 72, 7-28. doi: 10.1111/j.1463-6395.1991.tb00312.x

\section{ACKNOWLEDGMENTS}

We acknowledge the editor and the reviewers for providing helpful comments.

Passamaneck, Y. J., Hejnol, A., and Martindale, M. Q. (2015). Mesodermal gene expression during the embryonic and larval development of the articulate brachiopod Terebratalia transversa. EvoDevo 6:10. doi: 10.1186/s13227-015-0004-8

Santagata, S. (2015). "Brachiopoda," in Evolutionary Developmental Biology of Invertebrates 2: Lophotrochozoa (Spiralia), ed A. Wanninger (Vienna: Springer Vienna), 263-277.

Santagata, S., Resh, C., Hejnol, A., Martindale, M. Q., and Passamaneck, Y. J. (2012). Development of the larval anterior neurogenic domains of Terebratalia transversa (Brachiopoda) provides insights into the diversification of larval apical organs and the spiralian nervous system. EvoDevo 3:3. doi: 10.1186/2041-9139-3-3

Schiemann, S. M., Martín-Durán, J. M., Børve, A., Vellutini, B. C., Passamaneck, Y. J., and Hejnol, A. (2017). Clustered brachiopod hox genes are not expressed collinearly and are associated with lophotrochozoan novelties. Proc. Natl. Acad. Sci. U.S.A. 114, E1913-E1922. doi: 10.1073/pnas.1614501114

Schwaiger, M., Schonauer, A., Rendeiro, A. F., Pribitzer, C., Schauer, A., Gilles, A. F., et al. (2014). Evolutionary conservation of the eumetazoan gene regulatory landscape. Genome Res. 24, 639-650. doi: 10.1101/gr.162529.113

Skovsted, C. B., Balthasar, U., Brock, G. A., and Paterson, J. R. (2009a). The tommotiid Camenella reticulosa from the early Cambrian of South Australia: Morphology, scleritome reconstruction, and phylogeny. Acta Palaeontol. Pol. 54, 525-540. doi: 10.4202/app.2008.0082

Skovsted, C. B., Brock, G. A., Holmer, L. E., and Paterson, J. R. (2009b). First report of the early Cambrian stem group brachiopod Mickwitzia from East Gondwana. Gondwana Res. 16, 145-150. doi: 10.1016/J.Gr.2009.02.002

Skovsted, C. B., Holmer, L. E., Larsson, C. M., Högström, A. E., Brock, G. A., Topper, T. P., et al. (2009c). The scleritome of Paterimitra: an Early Cambrian stem group brachiopod from South Australia. Proc. Biol. Sci. B. 276, 1651-1656. doi: $10.1098 / \mathrm{rspb} .2008 .1655$

Vellutini, B. C., and Hejnol, A. (2016). Expression of segment polarity genes in brachiopods supports a non-segmental ancestral role of engrailed for bilaterians. Sci. Rep. 6:32387. doi: 10.1038/srep32387

Wei, Z., Range, R., Angerer, R., and Angerer, L. (2012). Axial patterning interactions in the sea urchin embryo: suppression of nodal by Wntl signaling. Development 139, 1662-1669. doi: 10.1242/dev.075051

Williams, A., Carlson, S. J., Brunton, C. H. C., Holmer, L. E., and Popov, L. (1996). A supra-ordinal classification of the Brachiopoda. Philos. Trans. R. Soc. Lond. B, Biol. Sci. 351, 1171-1193. doi: 10.1098/rstb.1996.0101

Zhang, Z., Holmer, L. E., Skovsted, C. B., Brock, G. A., Budd, G. E., Fu, D., et al. (2013). A sclerite-bearing stem group entoproct from the early Cambrian and its implications. Sci. Rep. 3:1066. doi: 10.1038/srep01066

Zhang, Z. F., Li, G. X., Holmer, L. E., Brock, G. A., Balthasar, U., Skovsted, C. B., et al. (2014). An early Cambrian agglutinated tubular lophophorate with brachiopod characters. Sci. Rep. 4:4682. doi: 10.1038/srep04682

Zhang, Z. F., Shu, D. G., Emig, C., Zhang, X. L., Han, J., Liu, J. N., et al. (2007). Rhynchonelliformean brachiopods with soft-tissue preservation from the early Cambrian Chengjiang lagerstatte of South China. Palaeontology 50, 1391-1402. doi: 10.1111/j.1475-4983.2007.00725.x

Conflict of Interest Statement: The authors declare that the research was conducted in the absence of any commercial or financial relationships that could be construed as a potential conflict of interest.

Copyright (C) 2017 Altenburger, Martinez, Budd and Holmer. This is an open-access article distributed under the terms of the Creative Commons Attribution License (CC $B Y)$. The use, distribution or reproduction in other forums is permitted, provided the original author(s) or licensor are credited and that the original publication in this journal is cited, in accordance with accepted academic practice. No use, distribution or reproduction is permitted which does not comply with these terms. 